\title{
ESSENTIAL OIL COMPOSITION OF THYMUS FALLAX FISCH. \& C.A. MEY. AT DIFFERENT GROWING ALTITUDES IN MAZANDARAN, IRAN
}

\author{
H. GHELICHNIA ${ }^{1, *}$
}

*E-mail: h.ghelichnia@areeo.ac.ir

Received: June 11, 2020. Revised: July 08, 2020. Accepted: July 16, 2020. Published online: Oct 16, 2020

\begin{abstract}
Thymus fallax Fisch. \& C.A. Mey. (Lamiaceae) is a permanent plant that grows in some mountain rangelands of Mazandaran province in Iran. The aerial parts of Thymus fallax were collected during flowering stage from mountain rangelands of Mazandaran province, in North of Iran. Around samples were collected from three altitudes $(2400 \mathrm{~m}, 2700 \mathrm{~m}$ and $3000 \mathrm{~m}$ a.s.1.), in mountain regions of Mazandaran province. The goal of current research was to assess the effect of altitude on the chemical composition and function of essential oil in Thymus fallax. The essential oil were obtained by hydrodistillation and analyzed by gas chromatography (GC) and gas spectrometry (GC-MS). Based on the results, the essential oil content is between $1.12-1.61 \%$ at different altitudes. The result of study show that the highest concentrated essential oil (1.61\%) was extracted in the lowest altitude $(2400 \mathrm{~m})$, while it was opposite, $(0.1 .12 \%)$ in the
\end{abstract}

highest altitude $(3000 \mathrm{~m})$. The main compounds of essential oil are: thymol $(5.95 \%$ - 10.06\%), carvacrol (13.63\% $69.04 \%), p$-cymene $(4.19 \%-12.18 \%)$ and borneol $(4.72 \%-5.66 \%)$. According to the results, altitude has a negative effect on the percentage of essential oils and essential oil decreases with increasing altitude. The altitude has a negative effect on the percentage of thymol and the content of thymol decreased with increasing altitude. The altitude has a positive effect on the percentage of carvacrol and the content of carvacrol increased with increasing altitude.

Keywords: carvacrol; mountain rangelands.

\section{INTRODUCTION}

The genus Thymus L. (Lamiaceae) consists of about 350 species of herbaceous perennials and subshrubs (Morales, 1986).

\footnotetext{
${ }^{1}$ Forest and Rangeland Research Department, Mazandaran Agricultural and Natural Resources Research Center, AREEO, Sari, Iran
} 


\section{H. GHELICHNIA}

The mediterranean region can be described as the center of the genus (Stahl-Biskup, 1991). Thymus species are commonly used as tonic, carminative, digestive, antitussive, expectorant and for the treatment of cold in Iranian traditional medicine. Recent studies imply that these species have strong antibacterial activities (Vila, 2002). The Iranian popular name for the genus is "Avishan" (Rechinger, 1982). A number of 18 Thymus species has been reported in flora Iranica and six of them have been known endemic (Abousaber et al, 2002; Mozaffarian, 1998). Thymus species are well known as medicinal plants because of their biological and pharmacological properties. In traditional medicine, the leaves and flowering parts of Thymus species are widely used as tonic and herbal tea, flavouring agents (condiment and spice), antiseptic, antitussive and carminative, as well as treating colds (Mirzaee et al., 2012; Zargari, 1990).

Thymus oils and extracts are widely used in pharmaceutical, cosmetic and perfume industry, as well as for the purpose of flavoring and preservation of several food products (British pharmacopoeia, 1988). The genus Thymus has made it one of the most popular plants throughout the entire world due to its volatile constituents.

Therefore, there is a considerable research interest in the compositional analysis of Thymus essential oils obtained from the aerial parts of the plant (Vila, 2002). The essential oil substances are thymol, carvacrol, $p$-cymene, $\beta$-pinene, $\gamma$-terpinene, $\beta$-caryophyllene, 1-borneol,1,8-cineole etc (Rustaiyan et al., 2000; Sefidkon and Askari, 2002).

It is believed that a part of these activities is due to its volatile constituents. Severity of environment associated with increasing altitude in mountain ecosystems can affect medicinal plants growth, as well as their chemical compositions. These variations might be due to the presence of different hemotypes, plants adaptation to the surrounding environment, and developmental stage. Recent studies have showed that Thymus species have strong antibacterial, antifungal, antiviral, antiparasitic, spasmolytic and antioxidant activities (Sefidkon and Askari, 2002; Zargari, 1990). Many studies on composition of essential oils from different Thymus species have been carried out, one of which is T. kotschyanus. The published results reveal that major volatile constituents obtained from the aerial parts of the plant are thymol,carvacrol, $p$-cymene, c-terpinene, b-caryophyllene, etc. (Guseinov et al.,1987; Kasumov and Gadzhieva,1980; Kulieva et al., 1979; Sefidkon et al., 1999).

According to a study conducted on Thymus serpyllum, altitude in the most areas has a negative impact on the quantity of oil (Abu-Darwish et al. 2009). In agreement, Habibi et al. (2007) also reported a negative correlation between the altitude and the quantity of essential oil in wild thyme oil of Thymus kotschyanus 
grown in Taleghan. Takaloo et al. (2012) studied the composition of the oil from Thymus migricus and showed that the highest yields were obtained in the flowering stage and at the lowest altitude. However, evaluating the effect of environmental factors on essential oil of Thymus kotschyanus in Iran found the altitude with a positive effect on the amount of essential oil while soil $\mathrm{pH}$ had a negative effect on the oil quantity of this species (Aminzadeh et al., 2010). Tabrizi et al. (2010) showed that the amount of oil in Thymus transcaspicus is correlated with the altitude and the quality of the oil depends on the region.

The aim of this research paper is to determine the chemical combination of the essential oils collected aerial parts of T. fedtschenkoi from North of Iran, during the flowering period, in five points altitude and effects of altitude on the amount and composition of essential oils. T. fallax species is an endemic species in Iran and Turkey, but mostly distributed in Iran. It is element of Iran-Turan (Rechinger, 1982). In spite of existence many reports of the essential oil composition and biological activity of Thymus species, only a few reports have been published on the essential oil of $T$. fallax (Barazandeh, 2004; Goze et al., 2009). Thymus fallax is widely distributed in Mazandaran province of Iran, from 2400-3500 $\mathrm{m}$ altitudes, growing on sandy and siliceous soils (Ghelichnia, 2010). It has been revealed that altitude has significant positive effect on the quality and quantity of essential oils of Thymus fallax in Lorestan natural habitats (Mohammadian et al., 2015).

The goal of current research is to assess the effect of altitude on the chemical composition and function of essential oil in Thymus fallax.

\section{MATERIALS AND METHODS}

\section{Plant material}

The aerial parts of $T$. fallax were collected during flowering stage, from mountain rangelands of Mazandaran province, in North of Iran. Random plot sampling design was used for collecting from 2400,2300 and $2000 \mathrm{~m}$ altitude with three replications and $50 \mathrm{~m}$ intervals in each altitude class. The size of used plots was $10 \times 10 \mathrm{~m}^{2}$. Voucher specimens were identified by Dr. Ziba Jamzad and deposited at the herbarium of Research Institute of Forests and Rangelands (RIFR), Tehran, Iran.

Table 1 - Geographical coordinates of sampling locations and the essential oil percentage of Thymus fallax growing at different altitudes in Mazandaran

\begin{tabular}{cccc}
\hline $\begin{array}{c}\text { Altitudes } \\
(\mathbf{m})\end{array}$ & Latitude & Longitude & $\begin{array}{c}\text { Essential oils } \\
(\%)\end{array}$ \\
\hline 2400 & $35^{\circ} 51^{\prime} 45.12^{\prime \prime} \mathrm{N}$ & $52^{\circ} 04^{\prime} 36.05^{\prime \prime} \mathrm{E}$ & 1.61 \\
\hline 2700 & $35^{\circ} 54^{\prime} 07.18^{\prime \prime} \mathrm{N}$ & $52^{\circ} 03^{\prime} 07.60^{\prime \prime} \mathrm{E}$ & 1.18 \\
\hline 3000 & $35^{\circ} 55^{\prime} 26.96^{\prime \prime} \mathrm{N}$ & $52^{\circ} 03^{\prime} 41.05^{\prime \prime} \mathrm{E}$ & 1.12 \\
\hline
\end{tabular}




\section{H. GHELICHNIA}

\section{Isolation of the essential oil}

After collection, the flowering aerial parts materials were shade dried at room temperature $\left(22-26^{\circ} \mathrm{C}\right)$ and placed inpaper pockets. Samples transferred to Laboratory of Research Institute of Forests and Rangelands (RIFR), Tehran, Iran. In order to estimate the rate of essential oils, the distillation method was used (Sefidkon et al., 1999). Dry plant matter were milled to a powder in an electric blender. The essential oil of all air-dried samples (100 g) was isolated by hydrodistillation for $4 \mathrm{~h}$, using a Clevenger-type apparatus, according to the method recommended in British Pharmacopoeia (Maisonneuve, 1983; British Pharmacopoeia, 1988). The essential oil yield of samples were calculated based on dry weight, and then the oil was dried over anhydrous sodium sulfate.

\section{Identification of compounds}

The constituents of the essential oils were identified by calculation of their retention indices under temperature programmed conditions for $n$-alkanes (C6-C24) and the oil on a DB-5 column under the same chromatographic conditions. Identification of individual compounds was made by comparison of their mass spectra with those of the internal reference mass spectra library or with authentic compounds and confirmed by comparison of their retention indices with authentic compounds or with those of reported in the literature (Adams, 2001). For quantification purpose, relative area percentages obtained by FID were used, without the use of correction factors.

\section{Statistical analysis}

The populations were compared for rate and components of essential oil by one-way analysis of variance (ANOVA) at SPSS 16 (statistical package program). Correlation analysis was also applied to determine the relations among the altitudes, rate and components.

\section{RESULTS AND DISCUSSION}

Mountainous areas of Mazandaran province in Northern Iran are the most important habitats of Thymus species. Different species of Thymus grow from $1300 \mathrm{~m}$ to $3500 \mathrm{~m}$ above sea level. The species $T$. fallax has the most habitat in Mazandaran. The essential oil content of the dried flowering aerial parts of $T$. fallax obtained by hydrodistillation, were yellow color and a distinct sharp odor. The geographic characteristics and altitudes of sampling points and the percentage of essential oils content of T. fallax are shown in Table 1. Based on the results, the essential oil content is between 1.12 and $1.61 \%$ at different altitudes (Table 1). The highest concentrated essential oil (1.61\%) was extracted in the lowest altitude $(2400 \mathrm{~m})$, while it was opposite $(1.12 \%)$ in the highest altitude $(3000$ $\mathrm{m})$. There is a significant difference between altitude and the percentage of essential oil. The percentage of essential oil decreases with increasing of altitude $(p \leq 0.05)$. The main components of the essential oils were thymol $(5.95 \%-10.06 \%)$, carvacrol (13.63\% - 69.04\%), p-cymene (4.19\% - 12.18\%) and borneol (4.72\% $5.66 \%$ ) (Table 2). The thymol chemotype yield is higher at lower and middle altitudes $(2400 \mathrm{~m}, 2700 \mathrm{~m})$ and decreases at higher altitude 
$(3000 \mathrm{~m})$. There is no significant difference in the percentage of thymol between the heights of $2400 \mathrm{~m}$ and
$2700 \mathrm{~m}$, but a significant difference showed at an altitude of $3000 \mathrm{~m}$ $(p \leq 0.05)$.

Table 2 - Amount of essential oil compositions of Thymus fallax growing at different altitudes in Mazandaran

\begin{tabular}{|c|c|c|c|c|}
\hline \multirow{2}{*}{ No. } & \multirow{2}{*}{ Compounds } & \multicolumn{3}{|c|}{ Altitudes } \\
\hline & & $2400 \mathrm{~m}$ & $2700 \mathrm{~m}$ & $3000 \mathrm{~m}$ \\
\hline 1 & Camphene & 1.5 & 2.65 & - \\
\hline 2 & $\alpha$-Pinene & 7.9 & 1.49 & 0.25 \\
\hline 3 & a-Phellandrene & 5.1 & 2.19 & 1.14 \\
\hline 4 & Myrcene & 2.89 & 1.47 & 1.51 \\
\hline 5 & Terpineolene & 1.03 & 0.32 & 0.08 \\
\hline 6 & $p$-Cymene & 7.73 & 12.18 & 4.19 \\
\hline 7 & $\mathrm{y}$-Terpinene & 3.68 & 8.68 & - \\
\hline 8 & 1,8-Cineole & 2.02 & 1.26 & 2.72 \\
\hline 9 & y-Terpineol & 2.80 & 0.66 & 1.59 \\
\hline 10 & Fenchone & 1.45 & - & - \\
\hline 11 & Linalool & 1.30 & 0.18 & 0.77 \\
\hline 12 & Camphor & 0.32 & 0.17 & 0.46 \\
\hline 13 & Pinol & - & 0.25 & - \\
\hline 14 & Borneol & 4.72 & 5.12 & 5.66 \\
\hline 15 & $\alpha$-Terpineol & 10.88 & 0.49 & 0.54 \\
\hline 16 & Bornyl acetate & 1.45 & 0.15 & 0.07 \\
\hline 17 & Geraniol & 9.27 & 4.35 & 0.30 \\
\hline 18 & Methyl thymol & 2.47 & - & 2.97 \\
\hline 19 & Thymol & 10.04 & 10.06 & 5.95 \\
\hline 20 & Carvacrol & 13.63 & 41.84 & 69.04 \\
\hline 21 & Geranyle acetate & 0.37 & 2.17 & - \\
\hline 22 & $\beta$-Selinene & 0.19 & 0.12 & 0.07 \\
\hline 23 & E-Caryophyllene & 1.38 & 1.37 & 0.55 \\
\hline 24 & Spathulene & 0.11 & 0.37 & 0.09 \\
\hline 25 & B-Caryophyllene & - & 0.35 & 0.86 \\
\hline 26 & Menthol & - & - & 0.16 \\
\hline 27 & Caryophyllene oxid & 0.39 & 0.12 & - \\
\hline Total & & 98.01 & 98.01 & 99.84 \\
\hline
\end{tabular}

The carvacrol chemotype yield is the highest value in the $3000 \mathrm{~m}$ altitude $(69.04 \%)$ and its lowest value is at $2400 \mathrm{~m}$ altitude $(13.63 \%)$. The relationship between altitude and amount of carvacrol showed a significant difference $(p \leq 0.05)$. The $p$-cymene chemotype yield is higher at middle altitudes $(2700 \mathrm{~m})$ and decreases at higher altitude $(3000 \mathrm{~m})$. The relationship between altitude and amount of $p$-cymene showed a significant differences $(p \leq 0.05)$. The amount of borneol in all altitudes is relatively the same. There is no significant difference between borneol levels at different altitudes $(p \leq 0.05)$. The results of the present study 


\section{H. GHELICHNIA}

focused on the effects of altitude factor of the quantity of essential oil in T. fallax. These results indicate that altitude factors could have an effect on the quality of the oil, which corresponds with the results of previous work on this genus (Boira and Blanquer, 1998; Omid Beigi, 1995). There is a significant negative correlation between altitude and the amount of essential oil and thymol (-0.94 and -0.84). There is a significant positive correlation between amount of carvacrol and altitude (0.99). There is no significant relationship between amount of $p$-cymene and borneol $(-0.42$ and 0.54$)$ (Table 3).

According to the results altitude has a positive effect on the percentage of carvacrol and the lowest amount of carvacrol is in the lowest altitude $(2400 \mathrm{~m})$ (Table 2). This is in agreement with the results of some previous works on the essential oil of Thymus kotschyanus (Habibi et al., 2007).

Table 3 - Relations among the studied characters

\begin{tabular}{cccccc}
\hline Characteristics & $\begin{array}{c}\text { Essential } \\
\text { oil (\%) }\end{array}$ & $\begin{array}{c}\text { Thymol } \\
(\%)\end{array}$ & $\begin{array}{c}\text { Carvacrol } \\
(\%)\end{array}$ & $p$-Cymene & $\begin{array}{c}\text { Borneol } \\
(\%)\end{array}$ \\
\hline Altitude & $-0.94^{* *}$ & $-0.84^{* *}$ & $0.99^{* *}$ & $-0.42^{\text {ns }}$ & $0.54^{\text {ns }}$ \\
\hline${ }^{* *}=$ significant $(p \leq 0.01) ; n s=$ no significant
\end{tabular}

The altitude has a negative effect on the percentage of thymol. The results of this study showed that the content of thymol decreased with increasing altitude and the highest amount of thymol is in the lowest and middle altitudes ( $2400 \mathrm{~m}$ and $2700 \mathrm{~m}$ ) and the lowest is in the highest altitude $(3000 \mathrm{~m})$ (Table 4). This is agreement with the result of essential oil of Thymus carmanicus in Iran (Ghasemi et al., 2013). According to the results, altitude has a negative effect on the percentage of essential oils and essential oil decreases with increasing altitude. This is in agreement with the results of some previous works on the essential oil of different species of the this genus (Habibi et al., 2007; Takaloo et al., 2012; Abu-Darwish et al., 2009; Imani Dizajeyekan et al., 2016), which states with increasing altitude, essential oil production will be limited and contrary to the results of Mohammadian et al. (2015) and Yavari et al. (2010). The study of essential oils of $T$. fallax from Turkey has shown that the main components were carvacrol and thymol and p-cymene, respectively (Tumen et al., 1999). Three chemotype of this study are similar to my study. The major constituents of the essential oil were carvacrol $(30.2 \%)$, geraniol $(15.4 \%)$ and $p$-cymene $(7.7 \%)$ in north of Iran (Morteza-Semnani et al., 2004). In contrast with this study, the results of my study show that the amount of carvacrol in the essential oil of T. fallax is high $(69.04 \%)$, that this amount has not been observed in other studies in north of Iran. The study has shown that the main constituents of 
the essential oil were carvacrol $(69.2 \%), p$-cymene $(15.4 \%)$, thymol $(5.3 \%)$ in the west of Iran (Rustaiee et al., 2011). This is in agreement with the results of my study but the borneol is not a main component of this study. The study of essential oils of $T$. fallax has shown that the main compouds of T. fallax are thymol $(43.43-61.14 \%)$, borneol
(3.89 - 7.01\%), carvacrol (3.88 $6.5 \%)$ and $p$-cymene $(4.58-6.0 \%)$ in east Azerbaijan in Iran. Although the main of the compounds are similar to my study, the amount of carvacrol is much higher in compared to this study, and this is related to the sampling of $T$. fallax essential oil at higher altitudes (up to $2500 \mathrm{~m}$ ), which has not been done in Iran.

Table 4 - The amount of essential oil, thymol, carvacrol and $p$-cymene rates of Thymus fallax at different altitudes

\begin{tabular}{cccccc}
\hline Location & $\begin{array}{c}\text { Essential oil } \\
(\%)\end{array}$ & $\begin{array}{c}\text { Thymol } \\
(\%)\end{array}$ & $\begin{array}{c}\text { Carvacrol } \\
(\%)\end{array}$ & $\begin{array}{c}p \text { - } \\
\text { Cymene }\end{array}$ & Borneol \\
\hline $2400 \mathrm{~m}$ & $1.61^{\mathrm{a}}$ & $10.04^{\mathrm{a}}$ & $13.66^{\mathrm{c}}$ & $7.73^{\mathrm{b}}$ & $4.72^{\mathrm{a}}$ \\
\hline $2700 \mathrm{~m}$ & $1.18^{\mathrm{b}}$ & $10.06^{\mathrm{a}}$ & $41.84^{\mathrm{b}}$ & $12.18^{\mathrm{a}}$ & $5.12^{\mathrm{a}}$ \\
\hline $3000 \mathrm{~m}$ & $1.01^{\mathrm{c}}$ & $5.95^{\mathrm{b}}$ & $69.04^{\mathrm{a}}$ & $4.19^{\mathrm{c}}$ & $5.66^{\mathrm{a}}$ \\
\hline
\end{tabular}

*The columns with different letters mean statistically different according to LSD $(\rho \leq 0.05)$ test.

\section{CONCLUSIONS}

The aerial parts of Thymus fallax were collected during flowering stage, from mountain rangelands of Mazandaran province, in the North of Iran. Samples were collected from four altitudes $(2400 \mathrm{~m}, 2700 \mathrm{~m}$ and $3000 \mathrm{~m})$. In conclusion, our results demonstrate the essential oil content is between $1.12-1.61 \%$, at different altitudes. The highest essential oil $(1.61 \%)$ was extracted in the lowest altitude $(2400 \mathrm{~m})$, while it was opposite $(1.12 \%)$ in the highest altitude $(3000 \mathrm{~m})$. There is a significant difference between altitude and the percentage of essential oil. The thymol chemotype yield is higher at lower and middle altitudes $(2400 \mathrm{~m}$, $2700 \mathrm{~m}$ ) and decreases at higher altitude $(3000 \mathrm{~m})$. The carvacrol chemotype yield is the highest value in the $3000 \mathrm{~m}$ altitude $(69.04 \%)$ and its lowest value is at $2400 \mathrm{~m}$ altitude (13.63\%).

Acknowledgement. This work was supported by Research Institude of Forests and Ranagelands, Iran.

\section{REFERENCES}

Abousaber, M., Hadjakhoondi, A. \& Shafiiee, A. (2002). Composition of the essential oil of Thymus pubescens Boiss. et Kotschy ex Celak and Thymus fedtschenkoi Ronniger from Iran. J.Essent.Oil Res., 14(3): 154-155, DOI: 10.1080/ 10412905.2002.9699808

Abu-Darwish, M.S., Abu-Dieyeh, Z.H., Mufeed, B., Al-Tawaha, A.R.M. \& Al-Dalain S.Y.A. (2009). Trace element contents and essential oil yields from wild thyme plant (Thymus serpyllum L.) grown at different natural variable 


\section{H. GHELICHNIA}

environments, J.FoodAgric.Environ., 7(3-4): 920-924.

Adams, R.P. (2001). Quadrupole mass spectra of compounds listed in order of their retention time on DB-5. Identification of essential oils components by gas chromatography/ quadrupole mass spectroscopy. Allured Publishing Co, Carol Stream, IL, USA, p. 456.

Aminzadeh, M., Amiri, F., Abadi, E.A., Mahdevi, K. \& Fadai, S. (2010). Factors affecting on essential chemical composition of Thymus kotschyanus in Iran. World Appl.Sci. J., 8(7): 847.856.

Barazandeh, M,M. (2004). Essential oil composition of Thymus fallax Fisch. \& C.A. Mey. from Iran. J. Essent. Oil Res., 16(2): 101-102, DOI: 10.1080/ 10412905.2004.9698661

Boira, H. \& Blanquer A. (1998). Environmental factors affecting chemical variability of essential oils in Thymus piperella L. Biochem. Syst.Ecol., 26(8): 811-822. British Pharmacopoeia (1988). Vol. 2, London: HMSO, pp. 137-138

British Pharmacopoeia (1988). Vol. 2, London: HMSO, pp. 137-138.

Ghasemi Pirbalouti, A., Barani, M., Hamedi, B., Ataei Kachouei, M. \& Karimi, A. (2013). Environment effect on diversity in quality and quantity of essential oil of different wild populations of Kerman thyme. Genetika, 45(2): 441-450, DOI: 10. 2298/GENSR1302441P

Ghelichnia, H. (2010). The study of ecological properties of Thymus species in Mazandaran, Iran. Agriculture and Natural Research Center of Mazandaran, $150 \mathrm{p}$.

Goze, I., Alim, A., Akkus Cetinus, S., Durmus, N., Vural, N. \& Murat Goze, H. (2009). Chemical composition and antioxidant, antimicrobial, antispasmodic activities of the essential oil of Thymus fallax Fisch. Mey. J.Med. Plant Res., 3(3): 174-178
Guseinov, S., Kagramanova, K.M., Kasumov, F.Y. \& Akhundov, R.A. (1987). Studies on the chemical composition and on some aspects of the pharmacological action of the essential oil of Thymus kotschyanus Boiss. Farmakologiya Toksikologiya, 50: 73-74.

Habibi, H., Mazaheri, D., Majnoon Hosseini, N., Chaeechi, M.R., Fakhr-Tabatabaei, M. \& Bigdeli, M. (2007). Effect of altitude on essential oil and components in wild thyme (Thymus kotschyanus Boiss) Taleghan region. Pajouhesh and Sazandegi, 4(19): 2-10.

Imani Dizajeyekan, Y., Razban Haghighi, A. \& Ebrahimi Gajoti, T. (2016). Quantitative and qualitative study of Thymus fallax essential oil in two habitats of East Azarbaijan province of Iran. University Journal of Science, 29(4): 959-962.

Kasumov, F.Y. \& Gadzhieva, T.G. (1980). Components of Thymus kotschyanus. Khim. Prir. Soedin., 1: 728-732.

Kulieva, Z.T., Guseinov, D.Y., Kasumov, F.Y. \& Akhundov, RA. (1979). Akademiya Nauk Azerbaidzhanskoi S.S.R. Doklady, 1(35):87-91.

Mirzaee, A., Jaberi Hafashani, H., Mirzaee, N. \& Madani, A. (2012). Antioxidant activities, total phenols and total flavonoids assay of Origanurm vulgare, Teucrium polium and Thymus daensis. Medical Journal of Hormozgan, 15: 285-294.

Mohammadian, A., Karamian, R., Mirza, M. \& Sepahvand, A. (2015). Effects of altitude and soil characteristics on essential oil of Thymus fallax in different habitats of Lorestan province. Iran.J.Med \& Arom. Plants, 30(4): 519-528.

Maisonneuve, S.A. (1983). European pharmacopoeia, 2nd ed. Vol. 1, Sainte-Ruffine, France, V.2.1.8V.2.1.8.10.

Morales Valverde, R. (1986). Taxonomía de los géneros Thymus (excluida de la sección (Serpyllum) y Thymbra en 


\section{ESSENTIAL OIL COMPOSITION OF THMMUSFAUAXAT DIFFERENT ALTITUDES}

la Península Ibérica. Ruizia. Monografias del Jardín Botánico 3, $324 \mathrm{p}$.

Morteza-Semnani, K., Saeedi, M. \& Changizi, S. (2004). The essential oil composition of Thymus fallax Fisch. \& C.A. Mey. from Iran. J.Essent.Oil-Bear. Plants, 7(3): 210216, DOI: 10.1080/0972-060X.2004. 10643394

Mozaffarian, V. (1998). A dictionary of Iranian plants names. Tehran: Farhang Moaser Publishers, pp. 547-548.

Omid Beigi, R. (1995). Propagation and production of medicinal plants. Vol. I. Fekrafroz Pub., Tehran, Iran, 283 p.

Rechinger, K.H. (1982). Flora Iranica (Eds, K.H. Rechinger), Akademische Druck-u. Verlagsanstalt, Graz, Austria, 150: 536-538.

Rustaiyan, A., Masoudi, S., Monfared, A., Kamalinejad, M., Lajevardi, T., Sedaghat, S. \& Yari, M. (2000). Volatile constituents of three Thymus species grown wild in Iran. Planta Medica, 66: 197-198.

Rustaiee, A.R., Sefidkon, F, Saeedi, I. \& Rasouli, M. (2011). Aromatic profile of Thymus fallax fisch. \& CA Mey. essential oil growing wild in Iran. J.Essent.Oil-Bear.Plants, 14(6): 782785, DOI: 10.1080/0972060X.2011. 10644004

Sefidkon, F., Dabiri M. \& RahimiBidgoly, A. (1999). The effect of distillation methods and stage of plant growth on the essential oil content and composition of Thymus kotschyanus Boiss. \& Hohen. Flavour Frag.J., 14(6): 405-408, DOI: $10.1002 /(\mathrm{SICl}) 1099-1026(1999$ 11/12)14:6<405::AID-FFJ853>3.0.C O;2-M

Sefidkon, F., Jamzad, Z., YavariBehrouz, R., \& Nouri-Sharg, D. (1999). Essential oil composition of Thymus kotschyanus Boiss. et Hohen from Iran. J.Essent. Oil Res.,
11(4): 459-460, DOI: 10.1080/1041 2905.1999.9701184

Sefidkon, F. \& Askari, F. (2002). Essential oil composition of 5 Thymus species. RIFR, Iranian.J. Med.Aromat. Plants Res., 12: 29-51.

Stahl-Biskup, E. (1991). The chemical composition of Thymus oils: a review of the literature 1960-1989. J.Essent. Oil Res., 3(2): 61-82, DOI: 10.1080/ 10412905.1991.9697915

Tabrizi, L., Koocheki, A., Moghaddam, P.R. \& Mahallati, M.N. (2010). Chemical composition of the essential oils from Thymus transcaspicus in natural habitats. Chem.Nat.Compd., 46(1): 121-124.

Takaloo, S.G, Hassani, A., Hassanpouraghdam, M.B., Meshkatalsadat, M.H., Pirzad, A. \& Heidari, M. (2012). Essential oil content and composition of Thymus migricus Klokov \& Desj-Shost. affected by plant growth stage and wild habitat altitude. Rom.Biotech. Lett., 17(1): 6982-6988.

Tumen, G., Yildiz, B., Kirimer, N,, Kürkçüoglu, M., \& Baser, K.H.C. (1999). Composition of the essential oil of Thymus fallax Fisch. et Mey. from Turkey. J.Essent. Oil Res., 11(4): 489-490, DOI: 10.1080/1041 2905.1999.9701192

Vila, R. (2002). Flavonoids and further polyphenols in the genus Thymus. In: Stahl-Biskup, E. and Sáez, F. (eds.) Thyme, The Genus Thymus, Taylor and Francis, London, pp. 144-176.

Yavari, A., Nazeri, V., Sefidkon, F. \& Hassani, M.E. (2010). Influence of some environmental factors on the essential oil variability of Thymus migricus. Nat.Prod.Commun., 5(6): 943-948, DOI: 10.1177/1934578X1 000500629

Zargari, A. (1990). Medicinal plants. Tehran University Press, Tehran, Vol. 4, p. 38 (In Persian). 